\title{
OBCOŚĆ I SWOJSKOŚĆ W PRZESTRZENI SZKOŁY I DOMU. OBRAZY NASTOLETNICH IMIGRANTÓW I REEMIGRANTÓW W WYBRANYCH POWIEŚCIACH DLA MLODZIEŻY Z POCZĄTKU XXI WIEKU (PO ROKU 2004)
}

\author{
Beata GromadzKa ${ }^{1}$ \\ (Uniwersytet im. Adama Mickiewicza w Poznaniu)
}

Słowa kluczowe: literatura dla młodzieży, powieść o dorastaniu, imigracja, reemigracja

Key words: literature for the young, a novel about growing up, immigration, re-emigration

\begin{abstract}
Abstrakt: Beata Gromadzka, OBCOŚĆ I SWOJSKOŚĆ W PRZESTRZENI SZKOEY I DOMU. OBRAZY NASTOLETNICH IMIGRANTÓW I RE-EMIGRANTÓW W WYBRANYCH POWIEŚCIACH DLA MŁODZIEŻY Z POCZĄTKU XXI WIEKU (PO ROKU 2004). „PORÓWNANIA” 20, 2017. T. XX, S. 157-172. ISSN 1733-165X. Tematem artykułu są wybrane powieści polskie, słoweńska i angielska adresowane do młodzieży, które łączą postaci głównych bohaterów, nastolatków próbujących znaleźć swoje miejsce w obcym kulturowo i hermetycznym środowisku. Na płaszczyźnie porównania znajdują się trzy kręgi: domowy, szkolny i lokalny, czyli ważne dla bohaterów przestrzenie ścierania się wpływów, walki o dominację, gdzie Obcy/Inny staje się łatwą ofiarą. Porównanie wspólnych tematów: dorastanie, szkoła, rówieśnicy, walka o swoje miejsce w grupie, poszukiwanie własnej drogi pokazuje podobieństwa i różnice w ujmowaniu takich problemów przez autorów powieści.
\end{abstract}

Abstract: Beata Gromadzka, OTHERNESS AND FAMILIARITY AT SCHOOL AND AT HOME. IMAGES OF TEENAGE IMMIGRANTS AND RE-IMMIGRANTS IN SELECTED NOVELS FOR THE YOUTH FROM THE EARLY TWENTY-FIRST CENTURY (AFTER 2004). “PORÓWNANIA" 20, 2017. Vol. XX, P. 157-172. ISSN 1733-165X. The topic of the article is developed around three selected novels: a Polish, Slovenian and an English one. All novels are addressed to the youth. These novels are linked by characters, teenagers who are trying to find their place in a foreign culture and a hermetic environment. There are three circles taken into consideration in the comparison: home, school, and local. These are spaces that are important for the main characters as the influences and fights for dominance clash; where the discrimination Alien/Other is an

1 E-mail: beatagr@amu.edu.pl 
easy label for a victim. The comparison of common themes: growing up, school, peers, fighting for a place in the group, search for their own purpose shows the similarities and differences in the recognition of such problems by the authors of the described novels.

Termin powieść dla młodzieży wyodrębniony jako osobna kategoria zwraca uwagę na wiek odbiorcy i sugeruje potrzebę uwzględnienia go jako ograniczenia czy też potencjału w doborze tematyki i skomplikowania gatunkowego.

Mam świadomość toczącej się przez lata wśród badaczy, i ciągle niezakończonej, dyskusji zarówno na temat sztucznego eksponowania kategorii wiekowej odbiorcy, jak i zacierania granicy między literaturą popularną dla dorosłych a tą dla młodzieży (zob. m.in.: Cieślikowski 9-21, Skrobiszewska, Smuszkiewicz, Adamczykowa). Posługuję się tym terminem z rozmysłem, podkreśla on bowiem szczególne zobowiązania literatury dla niedorosłych. Dostarczana młodemu odbiorcy za jej pośrednictwem prawda o świecie, obraz kultury, wzorce zachowań społecznych czy wyznawane wartości składają się na kapitał kulturowy i społeczny, na podstawie którego kształtuje się habitus jednostki. Jest to przekaz kierowany przez dorosłego do osoby dopiero wchodzącej w dojrzałe życie, przekaz, który, niezależnie od intencji, jest wpisany w świat przedstawiony. Więcej mówi on o tym, jak dorosły już autor chce widzieć świat nastolatków oraz jak rozpoznaje ich potrzeby i problemy, niż o samym świecie odbiorcy. Literatura dla niedorosłych zainfekowana jest nieusuwalną skazą perswazji niezależnie od tego, czy mamy do czynienia z utworami o mniej lub silniej obecnym wydźwięku umoralniającym, czy też manifestacyjnie odżegnującymi się od pouczania i wychowywania. To założenie skłania do uważnego przyjrzenia się podejmowanej w niej tematyce i używanym strategiom perswazyjnym.

W swoich rozważaniach skoncentruję się na pograniczu tzw. książki dziecięcej i młodzieżowej oraz młodzieżowej i dorosłej, czyli tzw. middlegrade (8-13 lat) i Young Adult (13-18 lat, dalej nazywana skrótem: YA) ${ }^{2}$. Przyjmuje się zazwyczaj, że jest to proza podejmująca problemy wieku dorastania, $\mathrm{z}$ tego powodu w jakiejś mierze odpowiedzialna za wychowanie i pomagająca zrobić krok ku dorosłości.

Autorzy współczesnej, powstałej w XXI wieku, obyczajowej powieści dla młodzieżowego odbiorcy nieustannie poszerzają krąg tradycyjnych tematów związanych z problemami wchodzenia w dorosłe życie. Tematyka literatury YA zazwyczaj kojarzona jest $\mathrm{z}$ problemami dojrzewania, ze stosunkami $\mathrm{w}$ rodzinie i relacjami rówieśniczymi, a przestrzenie, w których sytuowana jest akcja, to dom, szkoła oraz najbliższe otoczenie: podwórko, osiedle, ulica. Co prawda obecnie coraz silniej wkracza w sferę tabu, traktując o inicjacji seksualnej, wczesnym macierzyństwie, homoseksualizmie, przemocy domowej, patologiach w rodzinie, chorobach, niepełnosprawności, śmierci. Można długo wymieniać trudne problemy podejmowane

2 Zob.: Urbanowska. Kategoria YA przenika się z NA, czyli New Adult. Z reguły ta pierwsza dotyczy przedziału wiekowego 13-18, druga 18-25, rozróżnia się je też na podstawie tematyki. 
w najnowszych utworach dla młodszych i starszych czytelników, nie sposób wręcz oprzeć się wrażeniu, że krainy dzieciństwa i marzenia młodości znane z pogodnych powieści Kornela Makuszyńskiego zastąpione zostały obrazami piekła dorastania oraz samotności nastolatka w obliczu okrucieństwa świata dorosłych?3.

Nasycanie literackich światów przedstawionych obrazami przemocy i cierpienia ma swoje wychowawcze i psychologiczne konsekwencje. Dziecko wkracza w świat lektury za pośrednictwem dorosłego, który tłumaczy nierozumiane i oswaja lęki. Nastolatek czyta sam i samodzielnie musi uporać się z wywołanymi przez lekturę stanami i uczuciami. Młody odbiorca zwykle poszukuje książek, które pozwolą mu nawiązać emocjonalne relacje z bohaterami. I to afekty bohaterów, autentyzm przeżyć i realistyczna motywacja psychologiczna są dla niego ważniejsze niż prawdopodobieństwo zdarzeń ${ }^{4}$. Mechanizm wpływu stanów emocjonalnych literackich postaci na młodych odbiorców jest fenomenem jeszcze niewystarczająco zbadanym, ale zaobserwować go można między innymi w Internecie, gdzie na forach i portalach społecznościowych młodzi czytelnicy dzielą się świadectwami odbioru: „Czytałam, [powieść] urzekła mnie. Porusza moim zdaniem ważny a zarazem wzruszający temat więc jak najbardziej jestem na tak. Kilka razy płakałam, ale dość często mi się to zdarza podczas czytania” (17.11.2015) lub „Nie płakałam czytając tą książkę, ale $\mathrm{w}$ pewnych momentach naprawdę łapie za serce. Najbardziej podoba mi się koniec - taki niespodziewany" (18.12.2015)5. Młody czytelnik, przeżywając afekty literackiego bohatera, odczuwa emocje związane z lekturą, jednocześnie uczy się rozpoznawać, porządkować i opanowywać swoje uczucia.

Wymienione powody czynią z literatury YA ważną płaszczyznę do rozwijania samoświadomości czytającego podmiotu i kształtowania jego postawy społecznej. Proza dla dorastających czytelników jest rodzajem areny, gdzie toczy się swoista gra afektów (Czapliński). Autor wychodzi od własnych doświadczeń, emocji i spostrzeżeń ku podmiotowi, nastoletniemu odbiorcy, by nie tylko umożliwić mu lepsze zrozumienie świata i zachowania innych ludzi, ale też przekazać pewne, akceptowane kulturowo, wzory postępowania. Niezależnie od wybranej strategii narracyjnej i widocznej tendencji do redukowania wszechwiedzy dorosłego - często na rzecz ucieczki w niedojrzałość, niewiedzę młodzieżowego narratora - uczestnika zdarzeń (Leszczyński 2003: 117-129) - zawarty w powieści obraz świata jest propozycją aksjologiczną kierowaną ze świata dorosłych do świata niedorosłego odbiorcy.

Literatura YA w niewielkim stopniu dotyczy historycznych, politycznych czy społecznych problemów współczesnego świata. Bezrobocie, niskie zarobki, nie-

3 Pisze o tej tendencji między innymi Grzegorz Leszczyński w Wielkie małe ksiązki. Lektury dzieci. I nie tylko (Leszczyński 2015: 225-290), a potwierdzają prawdziwość obserwacji informacje o nowo wydanych książkach dla dzieci i młodzieży w czasopismach „Ryms” czy „Książki”.

4 Co tłumaczy niezwykłą popularność literatury fantasy.

5 Cytaty pochodzą z forum www.harry_potter.net.pl [Web: 04.09.2016 r.] a dotyczą powieści Greena Gwiazd naszych wina, zapis autentyczny. 
równości społeczne, konflikty zbrojne stanowią co najwyżej odległe tło dla losów bohaterów i ich przeżyć lub są zniekształcone przez konwencję baśniową czy fantasy (np. Rudniańska). Wśród gorących tematów współczesnego świata znajduje się niewątpliwie temat migracji, aktualny zarówno ze względu na masowe migracje Polaków po 2004 roku, jak i na problem tzw. kryzysu migracyjnego.

W jaki sposób i w jakim wymiarze literatura YA podejmuje temat emigranta, reemigranta, imigranta, uchodźcy? Jaki obraz przekazuje? Jak wartościuje spotkanie młodego Innego ze środowiskiem rówieśników? Na te pytania spróbuję odpowiedzieć $\mathrm{w}$ artykule. Wybrane utwory adresowane są do odbiorcy między 12 a 18 rokiem życia. Wszystkie analizowane powieści zostały opublikowane po 2004 roku, czyli po wstąpieniu Polski do Unii Europejskiej. To zdarzenie silniej wprowadziło do życia społecznego i kulturalnego temat migracji i różnorodności kulturowej. Trzy polskie powieści (w kolejności powstania): Ewy Grętkiewicz Szczękająca szczęka Saszy (2005), Grzegorza Gortata Do pierwszej krwi (2006), Barbary Gawryluk Moje Bullerbyn (2010). Obok wymienionych uwzględniam dwie powieści powstałe poza Polską, ale podejmujące podobny temat: Gorana Vojnovicia Czefurzy raus! (I wydanie 2008 rok Lublana, polskie tłumaczenie 2010) i powieść Sarah Croissan Kasieńka (I wydanie 2012, polskie tłumaczenie 2015). Wskazane powieści, jakkolwiek z rozmaitych perspektyw i w różny sposób, podejmują temat odmienności kulturowej oraz dróg młodych bohaterów do tożsamości indywidualnej i narodowej.

Można określić węzły tematyczne, w których spotykają się problemy właściwe dla literatury o dorastaniu i takie, które przynależą do nurtu migracyjnego. W każdej powieści pojawia się nastoletni bohater, który znalazł się w obcym dla siebie kulturowo i hermetycznym środowisku: uczący się przez rok w polskiej szkole Białorusin Sasza (Grętkiewicz), pochodzący z Hanoi Wietnamczyk Thanh, który zjawia się w warszawskim liceum (Gortat), Polka Natalia, która wyjeżdża na dwa lata z rodziną do Szwecji i tam kontynuuje naukę (Gawryluk), bośniacki nastolatek Marko, mieszkający w Słowenii, w Lublanie (Vojnović), oraz polska dwunastolatka Kasieńka, która wyjeżdża wraz z mamą do Londynu i tam trafia do szkoły (Croissan). Każdy z nich jest $\mathrm{w}$ wieku dorastania, co kumuluje i potęguje doznawane urazy oraz przeżywane upokorzenia, a czytelnikowi pozwala wniknąć w świat przeżyć bohatera, który nie zawsze negatywnie, ale zawsze intensywnie przeżywa to, co go spotyka.

Porównane zostaną trzy przestrzenie: dom, szkoła i najbliższe, lokalne otoczenie: osiedle lub ulica. Wybór wiąże się ze specyfiką obyczajowej literatury młodzieżowej, dla której są to miejsca o największej sile oddziaływania na bohaterów. Kategoria przestrzeni nie została wybrana przypadkowo. Skoncentrowanie losów młodych bohaterów w tych kręgach skutkuje dużym nasileniem podobnych problemów właściwych dla nich niezależnie od kontekstu narodowego. Szkoła, osiedle czy ulica to miejsca ścierania się wpływów, walki o dominację, gdzie Obcy/Inny staje się łatwą ofiarą. Dom oferuje swojskość wobec obcości boleśnie odczuwanej w szkole czy w lokalnym środowisku. W przeciwieństwie do szkoły jest miejscem, 
gdzie bohater znajduje, nawet jeśli nie pełne zrozumienie i oparcie, to niekiedy trudną i toksyczną, ale jednak miłość najbliższych.

\section{Migrant w przestrzeni szkoły}

Szkolna przestrzeń $\mathrm{w}$ wymienionych powieściach nie jest szczegółowo opisana, raczej ewokowana przez powszechnie znane rytuały, czytelnik kreuje ją w wyobraźni na podstawie własnych doświadczeń, rozpoznaje szkolne sytuacje i charakterystyczny podział ról. To przestrzeń dobrze znana, oswojona przez bohatera i czytelnika:

Najpierw było zwyczajnie, jak to na początku roku szkolnego. Przemawiał dyrektor, po nim - pani z komitetu rodzicielskiego. Jakiś pierwszak zaczął beczeć tak głośno, że nawet hymnu nie było dobrze słychać. Wreszcie wszyscy rozeszliśmy się do klas (Grętkiewicz 25).

Jeśli dziś wtorek, to lekcje otwiera historia. Skoro historia to bez ofiar się nie obędzie. Karakan ma zwyczaj - uśmiechając się zwodniczo, niemal nie rozglądając się po klasie chodzić krokiem starca między lawkami (Gortat 29).

Dzwonek, / Melodyjka dająca sygnał, / Że możemy wstać z miejsca. / Jesteśmy pod władzą Jego Przenikliwości. / Gdy zadźwięczy, Wstajemy jak lunatycy, / A potem znów milkniemy (Croissan 18).

Szkoła z założenia jest miejscem socjalizacji dzieci i młodzieży, jej struktura, organizacja i przestrzeń stanowią mikrokosmos społecznego życia. Tu młodzi ludzie nawiązują relacje koleżeńskie i przyjacielskie, uczą się współdziałać, badają granice dopuszczalnych zachowań. Szkoła to również odpowiednik greckiej agory, stanowi miejsce spotkań i ścierania się poglądów. Tu nawiązują się znajomości, przyjaźnie, tu kształtują się postawy. W omawianych powieściach jest ona dla bohaterów przestrzenią boleśnie przeżywanego odtrącenia:

Brązowe dzieci / Bawią się z brązowymi dziećmi. / Czarne dzieci / Bawią się z czarnymi dziećmi / [...] / Mnie nikt nie zaprasza do zabawy. / Powód: jestem zbyt biała. / Nikt nie lubi zbyt białych, / Wschodnio białych, / Białych jak zima w Polsce, / Przerażająco wampirzo białych (Croissan 21).

W klasie Sasza nie miał łatwego życia. Szczególnie Kuba i Damian nie dawali mu spokoju. - Szczękająca Szczęko, powiedz nam: telefony komórkowe u was na Białorusi są?

[...] Na przerwach wołali na niego Szczekaczka albo Rusek, chociaż tłumaczyłam, że jest Białorusinem, a jego dziadkowie byli Polakami (Grętkiewicz 43, 45). 
Odrzucenie i wykluczenie oraz wszechobecne ośmieszanie jest stałym motywem epizodów z klasowego życia migrantów. Drastycznie problem przedstawia powieść Vojnovicia, gdzie szkoła jest miejscem deintelektualizacji, degradacji i systemowego wykluczania:

Centrum Zawodowe to szkoła, którą Słoweńcy wymyślili, bo nie wiedzieli, co zrobić z wszystkimi czefurami ${ }^{6}$. I dlatego zrobili Centrum Zawodowe, najbardziej jebaną nijaką szkołę na świecie, w której najwięksi debile spośród nauczycieli gnoją nas wszystkich na - ić. [...] Jesteśmy motłochem i mogą z nami robić, co chcą. Żeby zrobić Centrum Zawodowe, trzeba być geniuszem. Bo nie ma, żeby ci ktoś pomógł, żeby ci dali czas, żebyśs się nauczył i tak dalej (Vojnović 133).

Grzegorz Gortat idzie jeszcze dalej i pokazuje przemoc wobec Wietnamczyka Thanha, którego nowi koledzy ze szkolnej ławki postanawiają bez powodu pobić z pomocą zaprzyjaźnionych chuliganów:

- Nie wiem. Nie jestem stąd. [mówi Thanh - B.G.]

- I w tym cały problem - kwituje Baczer. - Nie jesteś stąd.

- Normalnie przybłęda - podsumowuje Koń.

[...] - Każdy ma swoje miejsce - dorzuca Koń. - Powinieneś trzymać się swojego podwórka.

- Chyba nie do końca kapuje - powiedział Baczer.

Lacha markuje uderzenie lewą ręką. Chłopak próbuje się uchylić. Lacha uderza z prawej, nawet się nie wysilając. Nie bije mocno. Chłopak leci do tyłu, prosto na Konia (Gortat 53).

Nauczyciele nieświadomie lub z premedytacją uczestniczą w wykluczaniu, nawet jeśli mają dobre intencje lub za ich decyzjami stoi zawodowa wiedza:

Jeśli masz trzy poprawki, od razu znajdzie się czwarty mądrala, który dorzuci ci jeszcze jedną, żebyś miał z głowy. Tu nie ma tere fere. To jest pedalska robota. Dlatego każdego roku jesteś w drugiej klasie (Vojnović 133).

To, co następuje teraz przypomina teatralny happening - sztuka bez myśli przewodniej, zbiorowa improwizacja, w którą magister Borkuć daje się wciągnąć bez reszty.

- Jakie to budujące - oznajmia załamując ręce nad Thanhem. - Wiemy, jak wy tam u siebie żyjecie. Korupcja, zacofanie, represje, zero perspektyw. A tu, proszę, masz szansę normalnie żyć, uczyć się. Coś osiągniesz (Gortat 45).

6 Czefur, to pejoratywna nazwa przesiedleńca z republik dawnej Jugosławii, pochodząca z języka chorwackiego, początkowo używana na określenie Żyda (Vojnović 11). 
Wymyślili kulturalny sposób, / By powiedzieć, że nie nadążamy, / Ale i tak wychodzi na to samo: / Dają mi więcej czasu, bo / Mam "specjalne potrzeby”. / Nikt w szkole nie chce być specjalnie traktowany. / Ja chcę być taka sama jak wszyscy. / Nikt nie chce mieć specjalnych potrzeb (Croissan 61).

Mechanizmy alienacji przedstawione w omawianych powieściach zapożyczone są z wielu ksiażek powstałych w nurcie antypedagogiki, a ukazujących szkołę jako miejsce opresji. Obraz uzupełniony jest przez hiperbolizację przyczyn dyskryminowania w rówieśniczej grupie, takich jak niezrozumienie języka i nieznajomość kontekstu kulturowego, które są najczęstszymi powodami wykluczenia i upokorzenia bohatera-imigranta.

Wszystko jest inaczej! Wszystko!

W życiu nie przypuszczałam, że będę tęsknić za szkołą! Ale za moją, za tą w Krakowie. [...] Oni wszyscy mówią po szwedzku. To znaczy, po angielsku też trochę mówią, ale prawie cały dzień nic nie rozumiałam (Gawryluk 33).

Pani Warren pyta: „Mówisz po angielsku, dear?”, / Przykucając / z rękami na kolanach, / Jakby przywoływała spaniela (Croissan 14).

Pirania widocznie od razu chciała to sprawdzić, bo wcisnęła mu książkę w rękę i nakazała czytać! No to co miał robić? Zaczął czytać:

- Myszliwy poszedł na polowanie...

- Nie myszliwy, tylko myśliwy - poprawiła. [...] No dalej! - poganiała Saszkę.

- Nie zauważył i wpadł do przerębli. Jak się z niej wydostał, zęby mu szczekali z zimna.

Piotrek i Damian gruchnęli śmiechem. Kajtek wykrzykiwał:

- Ale numer, szczekali! Słyszeliście! Zęby szczekali, ja nie mogę!

[...] Te Ruski! Powiedz coś jeszcze, bo dobrze ci idzie - zachęcał go Kuba, który ciągle nie miał dość tej zabawy (Grętkiewicz 29).

Schronienia poszukują bohaterowie w przestrzeni nieoficjalnej szkoły, w szkolnych zakamarkach, poza zasięgiem wzroku nauczycieli oraz mściwych i okrutnych rówieśników: w kącie podwórka (Croissan 21), w ostatniej ławce (Vojnović 135). Po wkroczeniu w przestrzeń edukacji uczniowie tracą indywidualną tożsamość i stają się grupą, która musi podporządkować się pewnym zasadom w niej panującym. Miejsca przez nich zajmowane mają charakter symboliczny i rytualny, wśród nich ostatnia ławka to strefa poza zasiegiem wzroku i zainteresowania nauczyciela, miejsce stygmatyzujące i pozbawiające szansy na zmianę, to tam zasiadają najgorsi uczniowie. A szkolne zakamarki, przestrzenie nieoficjalne, nie-miejsca pozwalają na usunięcie się prześladowcom i ujście kontroli nauczyciela: „Chowam się / W kącie / Podwórka / Obok kranu z wodą, / Z nadzieją, że mnie / Zostawią w spokoju” (Croissan 21-22). 
Odczucie obcości i samotności spotęgowane jest przez psychiczne i cielesne problemy dorastania, widać to szczególnie w Kasieńce, której bohaterka zmaga się nie tylko z odrzuceniem, ale także z kompleksami i lękami związanymi ze zmieniającym się ciałem i wzmożoną wrażliwością:

Jestem owłosiona. / Mam grube / czarne / włosy / Pod pachami / I na nogach, / I między nimi też. [...] Nie wszystkie dziewczyny są okrutne. / Niektóre się odsuwają, / Gdy Claire zaczyna. / Niektóre się odwracają, / Nie biorą udziału. / To Klub Litościwych - / Dziewczyny, które patrzą na mnie / Z litością, gdy na WF-ie / Jestem jedyną osobą bez pary (Croissan 100, 111).

Siedemnastoletni Marko z powieści Vojnovicia swoją frustrację, wynikającą $\mathrm{z}$ braku perspektyw, poczucia odtrącenia i zepchnięcia na margines społeczeństwa, wyładowuje językową agresją i chuligańskimi wybrykami. Po podpaleniu osiedlowego śmietnika wykrzykuje:

Nikomu z nas, Adiemu, Dejanowi, Acowi i mnie, nigdy nie udało się coś takiego. To było dla całej naszej czwórki. Jesteśmy najwięksi, najwięksi. Wszyscy siedzieliśmy w ostatniej ławce i wszyscy ledwo zbieraliśmy swoje dwóje, i zawsze byliśmy nijacy, i kiedy nasi rodzice szli do szkoły, później wszyscy po kolei dostawaliśmy baty. I zawsze mieliśmy naganne zachowanie, i zawsze odwalaliśmy chałę, i zawsze byliśmy najgorszymi zerami, i wszyscy zawsze nas krytykowali, i byliśmy totalnymi luzerami. [...] I dlatego ten ogień jest dla całej naszej czwórki i dla wszystkich, którzy nam dopieprzali, bo nie szła nam ta szkoła, i nie szły nam szkolne koła [...] (Vojnović 164).

Główni bohaterowie powieści Vojnovicia i Croissan, Bośniak w Słowenii i Polka w Anglii mają poczucie nieusuwalnej podrzędności. Doświadczają nierówności w szkole, a ich rodzice pracują na poślednich stanowiskach, nieodpowiadających kwalifikacjom.

Wiedziałam, że będę inna, / Obca. / Wiedziałam, że nie będę rozumiała / Wszystkiego. / Ale myślałam, że może będę egzotyczna, / Jak ruda wiewiórka wśród szarych, / Tak, jak angielska dziewczynka byłaby egzotyczna w Gdańsku, / Ale nie jestem angielską dziewczynką w Gdańsku, / Jestem Polką w Coventry. / To nie jest to samo, / Ani trochę (Croissan 51).

Mama dostała pracę / W szpitalu. / Dopóki nie znajdziemy Taty, / Będziemy biedne. / Będziemy potrzebowały pieniędzy. / Mama będzie sprzątać, przynosić i wynosić. / Nie musi się odzywać do nikogo. / [...] Właściwie oni wolą, żeby nic nie mówiła. / Ma po prostu sprzątać, przynosić, wynosić (Croissan 23-24). 
Mamy inne języki ojczyste i inne talenty. Ale wszyscy jesteśmy utalentowani i wszyscy możemy robić wielkie rzeczy. Nie tylko wasze kujony. Ale was to nie obchodzi. Macie w dupie nas parszywych czefurów z ostatnich ławek. My jesteśmy dla was tylko tymi na - ić! (Vojnović 164).

Rówieśnicy szybko wskazują im miejsce w grupie wykluczonych, przezywają: polska lesbijka, czefur, Rusek. Ujawniają wrogie nastawienie i uprzedzenia, będące skutkiem negatywnych stereotypów, uproszczonych oraz dyskredytujących obrazów przedstawicieli innego narodu i kultury. Protekcjonalne traktowanie imigrantów przez kulturę przyjmującą jest źródłem niechęci do integracji i skutkuje zamykaniem się w hermetycznym środowisku.

Trzy pozostałe spośród analizowanych powieści powstałe w Polsce nie stawiają problemu tożsamości płciowej i świadomości narodowej zbyt drastycznie, kładąc akcent na udaną próbę znalezienia swojego miejsca w nowej grupie dzięki serdecznej atmosferze w szkole, profesjonalnie przygotowanym nauczycielom i życzliwym przyjaciołom (Gawryluk, Grętkiewicz) czy w wyniku ukrywania tożsamości sprawców pobicia przez Thanha (Gortat). W przypadku Kasieńki i Marka droga do znalezienia swojego miejsca nie jest łatwa i wymaga od nich przeciwstawienia się grupie lub samotnego wyjazdu do Bośni, w rodzinne strony ojca na swego rodzaju resocjalizację w domu dziadków.

Niezależnie od tego, jak głęboka byłaby alienacja bohaterów, autorzy omawianych powieści wskazują rozwiązania służące adaptacji w obcym środowisku. Pisarze wskazują sport, muzykę i taniec jako środki do znoszenia napięć i rozwiązywania konfliktów. Sukcesy w sporcie i wkład w rywalizację oraz zwycięstwo zespołu dowartościowuje młodego człowieka, którego do tego momentu nie chciała zaakceptować grupa. Pozbawiona słów zrytualizowana rywalizacja pozwala na zawiązanie interakcji na zasadzie równorzędności.

W powieści Grętkiewicz uznanie grupy przynosi Saszy zwycięski udział w zawodach pływackich:

Od tych zawodów trochę jakby się zmienił stosunek chłopaków do Saszki. Dalej wołali na niego - Szczekaczka, ale nie zaczepiali go na korytarzu i nie ryczeli tak głośno ze śmiechu, kiedy powiedział coś nie tak (Grętkiewicz 46).

Kasieńka z powieści o tym samym tytule na basenie, w czasie treningów i zawodów pływackich odzyskuje pewność siebie, zdobywa uznanie grupy i zainteresowanie angielskiego rówieśnika Williama: „Kiedy słyszę gwizdek, / Skaczę do wody z zaciekłością, / Której się nie spodziewałam, / A pragnienie, by wygrać / Pcha mnie naprzód / Przez wodę / Do końca basenu i z powrotem" (Croissan 190).

W powieściach Gawryluk i Gortata muzyka i taniec pozwalają na przezwyciężenie obcości oraz nawiązanie porozumienia między polską nastolatką Natalią i jej 
szwedzkimi kolegami. Podobnie jest w Do ostatniej krwi. Co ciekawe, w obu książkach jest to młodzieżowy nurt hip-hopu. Tylko Marko z powieści Czefurzy raus! traci szansę na lepszy los i wyrwanie się z getta Fužin, ponieważ zostaje wyrzucony z drużyny koszykarskiej za niesubordynację. Jest to moment, w którym bohater najboleśniej przeżywa odtrącenie, żal wywołuje wściekłość i agresję, co doprowadza do szeregu dramatycznych zdarzeń, aż po współudział w morderstwie.

\section{Migrant w przestrzeni domu, ulicy, osiedla, miasta}

Wydarzenia $\mathrm{w}$ powieściach dla młodzieży rozgrywają się $\mathrm{z}$ reguły $\mathrm{w}$ ograniczonej przestrzeni domu, ulicy, osiedla, rzadziej toczą się w całym mieście. Każde $\mathrm{z}$ tych miejsc jest nacechowane kulturowo i niesie ze sobą sensy symboliczne. $\mathrm{W}$ powieściach podejmujących temat migracji ta przestrzeń intensyfikuje i mnoży znaczenia.

Dom, mieszkanie, przestrzeń pokoju nastoletniego bohatera to obszar własny, oswojony, dobrze znany. Przemieszczenie, utrata osobistej przestrzeni, ulubionych przedmiotów jest często pierwszym bolesnym doświadczeniem, które dotyka młodego człowieka jako zapowiedź nieodwołalnej zmiany, wydziedziczenia i utraty tożsamości.

„Lubię ten pokój w wieżyczce. Ale Mój to jest pokój w Krakowie. Chociaż jest mniejszy i ciaśniejszy" (Gawryluk 111) - zapisuje w dzienniku bohaterka Mojego Bullerbyn. Przeprowadzka jest dla bohatera często końcem dziecięcego świata, wywołuje uczucie zagrożenia i bezdomności. Jest zapowiedzią pasma kolejnych bolesnych doświadczeń.

Mama wynajęła pokój / W Coventry / Będziemy tu mieszkać [...]. „To tylko jeden pokój” - mówię, / Mając na myśli: / Nie możemy tu mieszkać. / „To się nazywa s t u d i o" - / mówi Mama, / Tak jakby słowo / Mogło zmienić rzeczywistość (Croissan 12).

Namiastką straconego domu stają się pochodzące z niego przedmioty, kojarzone z nim zwyczaje, kulinaria, domowe rytuały: parzenie herbaty, jedzenie świątecznego karpia, pierogów, picie rakiji, oglądanie meczu, a nawet niedzielne kłótnie rodziców. Są obszarem obrony przed przewidywanym rozproszeniem tożsamości i niepokojącą podwójnością egzystencji:

Kiedy tu przyjechałam, wszystko było źle. I tak bardzo tęskniłam za moimi przyjaciółkami, za babcią i dziadkiem, za tańcami, za Krakowem, za moim pokojem, nawet za szkołą. I dalej tęsknię. Ale minęło kilka miesięcy i nie wyobrażam sobie, co by było, gdybym nie poznała ciebie, Matsa czy Selmy (Gawryluk 156). 
W niektórych powieściach (Moje Bullerbyn, Kasieńka i Czefurzy raus!) prawdziwy dom to pozostali w kraju rodzinnym dziadkowie. Odwiedziny reprezentantów starszego pokolenia przywracają porządek w rozbitym świecie i są krótkim, czasem iluzorycznym, powrotem normalności:

Śpiewamy kolędy, / Jemy karpia, / Otwieramy pudełeczka / Owinięte wstążkami, / I jest całkiem dobrze. [...] / Babcia szyje i śpiewa, / Stare, kościste palce prowadzą nitkę. / Szyje patchworkowe kapy na łózko / Ze starych koszul i spódnic - / Ubrania, których nikt nie chce, / Babcia zamienia w magię (Croissan 65).

Miejsce urodzenia lub pochodzenia: Polska, Białoruś, Bośnia to nieustanny punkt odniesienia. Stamtąd bohaterowie czerpią siłę do mierzenia się z migracyjną codziennością. To także przestrzeń gwarantująca ład moralny. Szczególnie wyraziście pokazany został ten problem w powieści Vojnovicia, gdzie jedynym pomysłem ojca Marko na ochronienie syna przed deprawacją i więzieniem jest wysłanie go na wieś do domu dziadków.

- U babki będziesz ładnie pracował, pomagał jej przy dziadku i dbał o dom. Żebyś nauczył się pracy i odzwyczaił od tych swoich durnot. Skończyły się żarty. [...] I będziesz pracował przy chlewie. Tak będzie dla ciebie najlepiej. Niech zrobi z tobą porządek raz dwa (Vojnović 171).

Rodowód rozumiany jako miejsce zakorzenienia nabiera w migracyjnych narracjach znaczeń ambiwalentnych. Nie zawsze jest to miejsce urodzenia bohatera, czasem, jak w przypadku słoweńskiej powieści, stamtąd pochodzą rodzice. Sam bohater, urodzony w Słowenii, nie ma już jednego punktu odniesienia, został skazany na wykluczenie także z własnego domowego obszaru, znalazł się na granicy, a właściwie w tożsamościowej pustce. Jego świadomość uległa rozbiciu i rozproszeniu. Najlepiej ilustruje to podróż Marko do rodzinnej wioski ojca. Spotkany w pociągu Bośniak nazywa bohatera Janezem, co jest pogardliwym określeniem Słoweńca. Warto przypomnieć, że Słoweńcy imigrantów z Bośni nazywają czefurami i tak o sobie mówi Marko: „Kto wytrzyma w tej Bośni? Bośnia nie jest dla nas czefurów. Być czefurem w Słowenii, do tego jestem przynajmniej przyzwyczajony, być Janezem w Bośni, to jest całkiem nowe bagno" (Vojnović 191).

W omawianych powieściach nakreślona została przestrzeń lokalna, najbliższa bohaterowi: sąsiedztwo, droga do szkoły, osiedle. Jest ona kontekstem pozwalającym zrozumieć postawę bohatera, daje poczucie przynależności, wyklucza lub pozwala na ponowne zadomowienie (Moje Bullerbyn, Czefurzy raus!, Do pierwszej krwi). Marko (bohater powieści Vojnovicia) mieszka na Fužinach, blokowisku zasiedlonym przez imigrantów głównie z Bośni. Tu bohater czuje 
się pewnie, zna reguły współżycia, normy postępowania, wie wszystko o osiedlowych zwyczajach.

Przesiadywanie pod blokiem to narodowy fužinski sport. Pewnie tak jest na każdym osiedlu, ale na Fužinach ta dyscyplina jest rozwinięta do maksimum. Kurde, małe mieszkania, duże rodziny, napięte stosunki, niski standard (Vojnović 32).

Blokowisko jest źródłem dodatkowej frustracji bohatera i jego bliskich. Złe warunki ekonomiczne, trudna sytuacja społeczna ${ }^{7}$ powodują postępującą degradację kolejnych pokoleń. Rodzice bezradnie patrzą na dzieci i młodzież, które nie mogą wyrwać się z kręgu bezrobocia i przestępczości, co jest spowodowane w dużym stopniu przynależnością narodową. Ambicje kulturalne zaspokaja oglądanie meczy piłkarskich w telewizji, picie na ławce pod blokiem lub w miejscowej knajpie Kubanie, a jedyną dostępną rozrywką jest palenie śmieci i jazda samochodem po centrum Lublany. Tak przedstawia życie mieszkańców Fužin Vojnović. Podobne problemy ukazuje Gortat w powieści Do pierwszej krwi - kilka szczegółów topograficznych wystarczy, by wykreować przestrzeń osiedlowego miejsca bez właściwości, przestrzeni symbolizującej brak centrum i tożsamości.

Standard: dziesięć pięter, trzy klatki, sto pięćdziesiąt mieszkań. Mieszkalny silos, w dole szlaczki graffiti. Za nim, w równych piętnastometrowych odstępach, trzy kolejne dziesięciopiętrowce. Po drugiej stronie betonowego placu następna bliźniacza czwórka mrówkowców. U wylotu placu rząd niskich blaszanych pawilonów: warzywniak, spożywczo-monopolowy, wypożyczalnia wideo. Dalej, oddzielony torowiskiem tramwajowym, obstawiony billboardami hipermarket. Z hipermarketem sąsiaduje biurowiec, do biurowca przylega prowizoryczny parking ogrodzony siatką ogrodową (Gortat 16).

Przestrzeń jest aksjologicznie nacechowana, jest symbolem nijakości i pustki. Na osiedlowej ławce, przed blokiem spędzają czas zarówno imigranci i dzieci imigrantów (Czefurzy raus!), jak i ich prześladowcy (Do pierwszej krwi). Anonimowe, zdegradowane wizualnie i aksjologicznie terytorium stanowi swoiste nie-miejsce (Augé), które jest antytezą swojskości i przestrzeni zindywidualizowanej, mającej swoją historię i pamięć. To przestrzeń pozbawiona sacrum:

W naszym bloku mieszkają źli ludzie. / [...] / Słyszymy złych ludzi każdej nocy, / Jak przeklinają Jezusa / I Wszystkich Świętych w Niebiosach. / Mama robi znak krzyża / I każe mi zmówić pacierz. / Więc mówię / Schowana pod pierzyną, / Z nadzieją, że Bóg usłyszy mnie / Tutaj / w Coventry (Croissan 29-30).

7 Po 1991 roku rząd Słowenii (w wyniku wojny z Jugosławią o niepodległość) odebrał obywatelstwo kilkunastu tysiącom ludzi, imigrantom z Jugosławii, odbierając im prawa. Przywrócono je w 1999 roku. 
Jednoznacznie wartościowana przestrzeń peryferii, uboga ekonomicznie i pusta aksjologicznie jest miejscem dramatu bohaterów. Marko i jego rodzina zostają w niej uwięzieni, bez perspektyw, bez szansy na odmianę losu. Gang Baczera z powieści Gortata zawłaszcza tę przestrzeń, dyktuje prawa - decydując, kto jest swój, a kto obcy - i realizuje je poprzez bójki, wymuszenia, kradzieże. Kasieńka i jej mama są w niej tymczasowo, do czasu zakończenia desperackiej próby odnalezienia taty.

Negatywnie nacechowanej przestrzeni trzech powieści przeciwstawić można sposób, w jaki Gawryluk wykorzystała topografię do zakorzeniania się bohaterki Mojego Bullerbyn w szwedzkim miasteczku. Odwiedziny u sąsiadów, zabawy z nowymi koleżankami, lokalne tajemnice sprzyjają łagodzeniu poczucia obcości. Dwa światy, ten pozostawiony w Polsce i ten nowy w Szwecji, skonstruowane są paralelnie, właściwie składają się z tych samych elementów: serdeczne przyjaciółki, ulubiony klub taneczny, życzliwi sąsiedzi, przyjaźni nauczyciele. Bohaterka w obu zaczyna się czuć u siebie, co uświadamia sobie w zakończeniu powieści: „«Będzie dobrze, Natalko» - tak mi wszyscy mówili. I chyba już jest dobrze" (Gawryluk 165). Owo chyba dotyczy poczucia płynności, które nie opuszcza dziewczynki do końca, tamten świat stracił swoją wyjątkowość, bo ma swój odpowiednik w innym miejscu. Natalia czuje się zawieszona między dwoma światami, choć nie jest to przyczyną konfliktu i niepokoju, ale poczucia, że jest wiele miejsc, w których można czuć się swojsko. Takie jest przesłanie powieści Gawryluk. Autorka idzie dalej, kreując szwedzkie miasteczko na wielokulturową idyllę, gdzie kolejne pokolenia imigrantów znajdują swój dom, jak Selma, lwowska primabalerina, od lat mieszkająca przy tej samej, co rodzina Natalii, ulicy. Jej postać wprowadza motyw utraconych Kresów, z którym związani są w różny sposób starsi i młodsi bohaterowie. Lwów jest miejscem sentymentalnym, symboliczną, wielokulturową arkadią, która znosi podziały narodowe i pokoleniowe.

Omawiana grupa powieści uświadamia potrzebę niezbędnego do zadomowienia i złagodzenia obcości wspólnym z krajem pochodzenia imigranta kontekstem kulturowym. W powieści Gawryluk bohaterowie odwiedzają Junibacken, ogród zabaw z postaciami z utworów Astrid Lindgren i innych bajek dla dzieci. Wspólne dla dzieciństwa postacie z literatury nie tworzą bariery językowej i kulturowej.

A bliźniacy odśpiewali całą pierwszą zwrotkę po polsku. Potem znowu był refren i wtedy każdy śpiewał w swoim języku, my po polsku, piraci i Pippi po szwedzku, rodzina koło nas po angielsku, a trzy dziewczynki, które siedziały przed nami, nie wiem w jakim języku. Tata mówił, że chyba po fińsku (Gawryluk 139).

Dla bohatera powieści Vojnovicia aktualnie odczuwane niezrozumienie i wrogość ma swoje źródło w braku wspólnych lektur z dzieciństwa. Nie ma szansy na porozumienie i współżycie w równoległych światach, które nie mają ze sobą kulturowo i topograficznie nic wspólnego, mimo że kiedyś stanowiły jedno państwo. 
Nie mamy my i Słoweńcy szans. Wszystko się zaczyna już jak jesteśmy dziećmi i im starzy czytają jebane Pedenjpedy i Muce Copatarice, a nam Domki Jeża i Grgi Čvarki I od tego momentu [...] każdy idzie w swoją stronę i nie ma siły, żeby ktoś nas pogodził. My możemy się niby przyjaźnić i kumać, i czasem udawać kolegów i tak dalej, ale nie możemy naprawdę się pokumać. Tak po bratersku. Po prostu nie mamy tych samych rzeczy we krwi i koniec. My jesteśmy czefurami, a oni są Słoweńcami, i to jest to. Trudno. Wszystkiemu są winni Branko Ćopić i Jovan Jovanović Zmaj ${ }^{9}$ (Vojnović 75).

\section{Podsumowanie}

Omawiane powieści stanowią interesujący przykład mierzenia się autorów z aktualną tematyką migracyjną przy pomocy znanej formy powieści o dojrzewaniu adresowanej do młodego odbiorcy. Na ile właściwe są one dla etnosu czy kraju, w którym powstały? Jak prezentowany jest w nich temat obcości i inności? Jak przedstawiany jest temat spotkania kultur?

Odpowiedź na te pytania nie jest łatwa ze względu na omówione w części wstępnej artykułu założenia literatury dla młodego odbiorcy i ukazywanie motywu przemiany, dojrzewania bohaterów pod wpływem doświadczeń. Dla każdego z bohaterów bycie Innym lub spotkanie z Nim jest ważnym momentem dojrzewania, otwiera oczy na świat, uczy empatii, pogłębia rozumienie samego siebie i swojej roli wśród rodziny i rówieśników. Jest katalizatorem intensyfikującym wkraczanie w dorosłość, nawet gdyby to było uświadomienie sobie podrzędności. Pomaga kształtować tożsamość, która z racji bycia migrantem charakteryzuje się płynnością i rozproszeniem.

Można wyznaczyć wspólne cechy wynikające ze specyfiki formy. Jest to charakterystyczna geopoetyka, miejsca i nie-miejsca oddziałujące na bohaterów. Różnie są waloryzowane, ale w zasadzie podziały przebiegają między kategoriami swojskie/ obce, znane/tajemnicze, bezpieczne/niebezpieczne, centralne/peryferyjne.

Interesujący dla badacza jest wybór narracji wykorzystywanej do opisywania doświadczeń migracyjnych. Cztery na pięć powieści napisane są w formie pierwszoosobowej, jest to popularna forma oddawania głosu nastolatkowi dla sugestywniejszego i bardziej wiarygodnego prezentowania świata przeżyć bohatera poprzez usunięcie się dorosłego autora na margines. Jednak w niektórych powieściach ton młodzieżowej narracji brzmi nieco fałszywie - tak jest w powieści Grętkiewicz. Autorka wybiera humorystyczny styl i opowiada historię rocznego pobytu Saszy w Polsce z perspektywy Karoliny, córki rodziny goszczącej dalekiego krewnego z Białorusi. Ten zabieg skutkuje dość stereotypowym obrazem nawiązywania przy-

8 Są to postacie i motywy ze słoweńskiej, chorwackiej i serbskiej literatury dla dzieci.

9 Znani serbscy poeci, autorzy utworów dla dzieci. 
jaźni i bezkonfliktowego w zasadzie aklimatyzowania się chłopca. Zabawne przygody przeżywane przez parę bohaterów w domu, w szkole i na osiedlu są charakterystyczne dla przygodowych książek dla starszych dzieci. Powieść Gawryluk pisana jako pamiętnik z pobytu nastolatki wraz z rodziną w Szwecji zawiera silne przesłanie możliwości przekraczania kulturowych barier i jest mało realna $\mathrm{w}$ ukazywaniu świata bez konfliktów, gdzie każdy znajdzie swoje miejsce dzięki talentom i pomocy społeczności lokalnej oraz nauczycieli. Na tym tle powieści słoweńska i angielska zaskakują prawdziwością zarówno w ukazywaniu problemów imigrantów, jak i w nieunikaniu drastyczności. Vojnović wiarygodnie odzwierciedla wyrażane agresją i chuligańskimi wybrykami frustracje młodych ludzi pozbawionych perspektyw i skazanych na fužinskie getto lub wyjazd do zniszczonej wojną Bośni, gdzie świat się zatrzymał. Croissan oczami Cassy/Kasieńki widzi cierpienie rodziny, rozbitej przez wyjazd ojca i znalezienie sobie przez niego nowego miejsca w Anglii. Rozdarta między współczuciem dla matki i przywiązaniem do ojca bohaterka sama przeżywa ból dorastania opuszczona przez najbliższych i pozbawiona wsparcia. Samotnie walczy o nowe przyjaźnie i miłość.

Dla młodego odbiorcy literackie obrazy obcości rówieśników są lustrem, w którym odbija się ich obcość wobec świata, do którego dopiero wkraczają. Lektura powieści o Obcym/Innym jest dla niedorosłego czytelnika lekturą o nim samym, pokazuje, jak szukać porozumienia ze światem, poznawać siebie i innych.

\section{BIBLIOGRAFIA}

\section{Źródła}

Croissan, Sarah. Kasieńka. Przeł. Katarzyna Domańska. Warszawa: Wydawnictwo Dwie Siostry, 2015. Gawryluk, Barbara. Moje Bullerbyn. Łódź: Wydawnictwo Akapit Press, 2010.

Gortat, Grzegorz. Do pierwszej krwi. Wrocław: Zakład Narodowy im. Ossolińskich. Wydawnictwo, 2006. Grętkiewicz Ewa. Szczekająca szczęka Saszy. Warszawa: „Nasza Księgarnia”, 2005.

Vojnović, Goran. Czefurzy raus!. Przeł. Tomasz Łukaszewicz. Gdańsk: Wydawnictwo Międzymorze, 2010.

\section{Opracowania}

Adamczykowa, Zofia. Literatura dla dzieci. Funkcje. Kategorie. Gatunki. Warszawa: Wyższa Szkoła Pedagogiczna Towarzystwa Wiedzy Powszechnej, 2001.

Augé, Marc. Nie-miejsca. Wprowadzenie do antropologii hipernowoczesnej. Przeł. Roman Chymkowski. Warszawa: Wydawnictwo Naukowe PWN, 2010.

Cieślikowski, Jerzy. Literatura osobna. Wyb. Ryszard Waksmund. Warszawa: "Nasza Księgarnia", 1985.

Czapliński, Przemysław. „Poetyka afektywna i powieść o rodzinie”. Kultura afektu - afekty w kulturze. Humanistyka po zwrocie afektywnym. Red. R. Nycz, A. Łebkowska, A. Dauksza. Warszawa: Instytut Badań Literackich PAN. Wydawnictwo, 2015. S. 372-401. 
Leszczyński, Grzegorz. Literatura i książka dziecięca. Stowo-Obiegi-Konteksty. Warszawa: CEBID 2003.

Leszczyński, Grzegorz. Wielkie małe ksiażki. Lektury dzieci. I nie tylko. Poznań: Media Rodzina, 2015.

Rudniańska, Joanna. Mój tata z obcej planety. Lasek: Wydawnictwo Pierwsze, 2008.

Skrobiszewska, Halina., "Literatura dla dzieci i młodzieży”. Słownik literatury polskiej XX wieku.

Red. A. Brodzka i in. Wrocław, Kraków, Warszawa: Zakład Narodowy im. Ossolińskich, 1992. S. 559-571.

Smuszkiewicz, Antoni. „«Czwarta» czy «osobna»"? (O literaturze dla dzieci). Konteksty polonistycznej edukacji. Red. M. Kwiatkowska-Ratajczak, S. Wysłouch. Poznań: Poznańskie Studia Polonistyczne. Seria Literacka, 1998. S. 357-370.

Urbanowska, Agnieszka. „Książka dla młodzieży w Polsce - okiem wydawcy”. Nowa Dekada Krakowska 1/2 (2016). S. 26-33. 